\section{Facts on Literacy and Disabilities}

\author{
Literacy Alberta \\ reprinted with permission from Myra Skerrett
}

Learning disabilities affect at least $10 \%$ of Canadians. More than $80 \%$ of these experience difficulty in learning to read.

Learning disabilities (LD) are now recognized as a lifelong neurological disorder that is the result of a difference in brain structure and function. Learning disabilities impact the learning process, including language learning and the acquisition of literacy skills. LD's can be divided into five types

- Visual problems: poor visual memory, reversals in writing;

- Auditory problems: poor auditory memory, speech problems;

- Motor problems: poor hand-eye coordination;

- Organizational problems: poor ability in organizing time or space;

- Conceptual problems: poor social skills and peer relations, difficulty in correctly interpreting non-verbal language.

For the newly revised, full definition of learning disabilities consult the Learning Disabilities Association of Canada at

http://www.ldac-taac.ca/

People with learning disabilities CAN learn with the appropriate supports. Learning disabilities need not prevent an individual from leading a productive and happy life. LDs are not due to a lack of intelligence but rather to deficiencies in acquiring and processing information. In fact people with LDs often have average or above-average intelligence but the LD affects their ability to interpret what they see or hear or to link information from different parts of the brain. They can learn but the learning process may be inefficient as a result of differences in brain structure and function. The right learning strategies, techniques, supports and interventions can impact the learning process in significant and positive ways.

It is estimated that $30-80 \%$ of students in literacy and basic education programs have learning disabilities. Learning disabilities affect at least $30 \%$ of the less literate population. Researchers have found that if LD intervention is not provided before the age of 8 , then there is a $75 \%$ probability of reading difficulties continuing into high school. At that point, $35 \%$ of students who are identified with learning disabilities drop out of high school. This is twice the rate of non-LD peers. This drop out rate does not include students who drop out but are not identified with learning disabilities. As adults many arrive in literacy and basic skills programs, however the majority drop out as programs are still not funded to be able to meet their special needs.

Learning and literacy difficulties limit participation in all aspects of society. Many adults are not aware that the problems they had in school, jobs or relationships are due to "hidden" or undiagnosed LDs. These difficulties are often compounded by, or result in, literacy problems. Disproportionate numbers of adults with LDs can be found in prisons $(30-70 \%)$, on welfare $(25-40 \%)$ and in job training programs $(15-30 \%)$.

\section{What can be done?}

- Accessible assessment and diagnosis of LD must be available for people of all ages.

- Effective and efficient learning and teaching methods, resources and programs must be funded and developed to meet the specific needs of individuals with LD.

- Policy-makers, school board administrators, teachers colleges, educators and medical personnel must recognize and accept the scientific evidence, establish policies, and match the instructional goals, content and pace of teaching to the learning needs of those with LDs so that individuals can achieve maximum success.

- Federal and provincial governments need to understand the implications of policy decisions, services and programs in the Canadian educational, legal, health, finance environmental and justice systems, for people with LDs.

- We all need to understand, recognize and support the unique learning challenges and needs of others in our communities, workplaces and families.

\section{Suggested Literacy and Learn- ing Disabilities Resources}

The Learning Disabilities Association of Canada (LDAC) The national support organization for all the provincial and territorial Learning Disabilities Associations (LDAs). Each provincial/territorial LDA in turn supports member chapters at the community level. All these organizations have created innovative projects and produced resources in a variety of formats. To check your local, provincial or national LD contacts, call $613-238-5721$ or visit LDAC's website at www.ldac-taac.a

Adult Learning Development Association (ALDA) is a BC-based non-profit association in support of adults who have 
learning disabilities. They provide both direct service programs and public education. For information contact ALDA in Vancouver at tel: 604-683-5554 or

www.alda-bc.org/

The Canadian Dyslexia Association. Find out more about dyslexia which is estimated to affect 1 in 6 Canadians at www.dyslexiaassociation.ca/

The Centre of Literacy of Quebec has a large collection of LD resources available for borrowing at www.nald.ca/litcent.htm

Children and Adults with Attention Deficit Disorder (CHADD) works to improve the lives of people with Attention Deficit/Hyperactivity Disorder through education, advocacy and support.
Tel: 613-731-1209 or online at http.chadd.org/

LD Online An excellent US-based informative website at www.ldonline.org/

Learning Disabilities Resources A constantly updated website where people exchange useful resources and information. Check it out at www.Idresources.com/

National Adult Literacy Database (NALD) The National Adult Literacy Database has a large collection of online resources and links for learning disabilities information at www.nald.ca/

National Coalition for Learning Disabilities This website is a US information and referral service that provides the latest information on LD and relevant resources that are available to parents, teachers and LD adults. Go to www.ncld.org/

The National Institute for Literacy (NIFL) has a Literacy and Learning Disabilities Special Collection at www.nifl.gov/lincs/collections/collections.html

University of Toronto's Adaptive Technology Resource Centre University of Toronto's website for their Adaptive Technology Resource Centre at www.utoronto.ca/atrc/

(Click on Web Resources for the learning disabilities section)

Literacy Alberta gratefully acknowledges the support of Movement for Canadian Literacy (MCL)

\section{A New Canadian Book of Art, Poetry and Music}

\section{Melissa Vassallo}

$\mathrm{R}$ ecently I participated as a proof reader of a very unique Canadian book, North America in Picture, Poetry and Piano. It is special because three talented and highly venerated Canadians collaborated to bringing together music painting and poetry within the context of a hard cover edition. Pierre Berton, a friend of the authors wrote the forward describing the venture as "a true celebration in words, music and poetry of the goodliest continent that we ever saw". It is a work that should be used in classrooms and homes to invite children on a journey of North America. The book brings together the art of Ted Harrison, the poetry of Lister Sinclair and musical improvisations by Gloria Saarinen of works composed by Oscar Peterson, Samuel Barber,
Franz List and others. The book is full of vibrant, colourful, and original art work portraying the melodious poetry of Sinclair. Included is an intriguing play along or play alone CDROM. Teachers and students can read, listen and hear the sounds of North America from the Pacific to the Atlantic, from the Pueblos to the Great Boreal Forest, from the land of the midnight sun to Florida palm trees and from the Prairies to French Canada. One of my favourite renditions involves the music of Rimsky Korsakov's "Flight of the Bumblebee" and Rachmaninoff's "Midsummer's Night Dreams" that brings alive Sinclair's Hoodo Dust Devils as they play at being "mischievous, capricious tricksters of the land from Banff to Bryce". If encouraging literacy is the focus of this issue of the jour- nal then this book provides a platform on which your readers can immerse themselves and invite others to participate in the richness of a Canadian collaboration of words, music and art. The book is available from Key Connections Oakville, Ontario, Canada.

Contact

Estelle@keyconnections.ca for additional information. ISBN0-9736227-0-9

Melissa Vassallo is a recent Queens University Graduate with an Honours Degree in

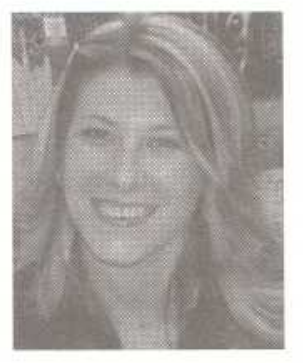
English. As an emerging freelance writer and editor Melissa has accepted an offer to edit the CFUW, Women's Executive newsletter

and agreed to review selected books for Teaching and Learning She is currently conducting a series of biographical interview with Lister Sinclair. 